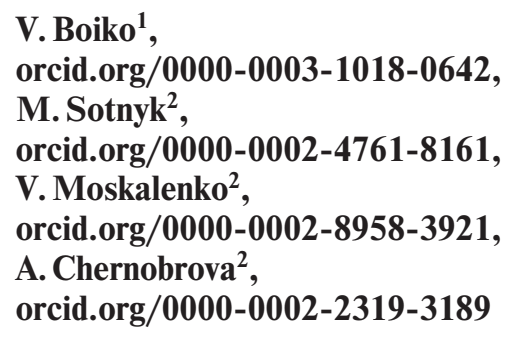

\title{
RECIRCULATION POWER IN THE BALANCE OF HYDRAULIC LOSSES OF CENTRIFUGAL PUMP
}

Purpose. Improving the methodology for determining the recirculation power of low and medium specific speed centrifugal pumps in order to determine ways to increase their energy efficiency.

Methodology. A numerical simulation based on the physical nature of the phenomena of recirculation power, conducted using the ANSYS CFX software.

Findings. The dynamics of changes in the integral parameters of the operational process of a centrifugal pump D2000-100-2 at flow rates that deviate from optimal $\left(Q_{o p t}\right)$ are investigated and presented. Based on the results of the numerical simulation, the values of the theoretical head of the impeller, as well as the head at its outlet, taking into account and excluding recirculation, are determined. Due to the difference in the obtained head values, the value of the power losses for recirculation and their part in the balance of hydraulic losses are determined. Based on the simulation results of the operational process of the centrifugal pump D2000-100-2, it is shown that part of the recirculation losses in the flow rate range $(0.7-0.4) \cdot Q_{o p t}$ is $25-30 \%$ of the total hydraulic losses, while in the flow rate range $(0.3-0.1) \cdot Q_{\text {opt }}$ it increases to $44 \%$.

Originality. Further development of the method for determining the recirculation power which is based on the results of numerical simulation of three-dimensional fluid flow in the flowing part of the centrifugal pump, taking into account the circulation vortex processes at the outlet of the impeller.

Practical value. Definition of the recirculation power in the power balance of hydraulic losses at the pump design stage. Taking account of the influence of the design parameters of the impeller on the value of recirculation.

Keywords: pump, energy, energy efficiency, recirculation, back flows

Introduction. The investigating of the physical nature and value of energy losses in all operating load range of a pump unit is the first step towards increasing its energy efficiency.

Hydraulic losses constitute a significant part of the energy losses during the operation of the pump in non-optimal load. At the same time hydraulic losses in the centrifugal are least studied.

Hydraulic losses are the total losses due to the flow of fluid through water channels. They can be conditionally divided into three categories:

- friction losses when the fluid flows in the channels of the flowing part of the pump;

- vortex losses which are caused by flow separation during the flowing around different elements of the pump flowing part;

- losses due to recirculation resulting from the formation of back flows at the inlet and outlet of the impeller in flow rates that deviate from the optimal one [1].

The above types of hydraulic losses are closely interconnected. It is difficult to determine their influence on each other, as well as the effect of the design parameters of the pump on their value.

The structure of hydraulic losses changes during the exploitation of a pump unit at various flow rates $-Q$. When the pump flow rate is less than optimal, the proportion of recirculation losses in the power balance increases. Therefore, the methodology for determining the value of these losses is an important factor in constructing and evaluating the curve $H=$ $=f(Q)$.

Improving the methodology for determining the value of recirculation will clarify the dependence of the value of recirculation on the design parameters of the pump.

Literature review. Energy losses due to recirculation are caused by back flows at the inlet and outlet of the pump impel-

(C) Boiko V., Sotnyk M., Moskalenko V., Chernobrova A., 2020 ler. Fluid recirculation occurs when the pump operates at nonoptimal load and is accompanied by additional energy losses, pressure pulsations, unsteady radial, and axial forces, noise and cavitation. Even in pumps with stable characteristics during operation at non-optimal load, the recirculation occurs inevitably.

In the design of centrifugal pumps of low and medium specific speed, the value of power losses on the recirculation is usually determined using theoretical or semi-empirical dependencies [2-4].

When using theoretical dependence to determine the power of recirculation at the impeller outlet of the pump, B. Ovsyannikov distinguishes two zones (Fig. 1): the active flow region $0-S_{1}$ and the vortex zone $\left(S_{1}-S_{2}-S_{3}\right)$.

On the surface $S_{1}-S_{2}$ of the vortex zone, fluid flows out of the impeller, and on the surface $S_{2}-S_{3}$ fluid flows back into the impeller. We denote the circumferential component of absolute velocity in the forward flow zone $S_{1}-S_{2}$ as $\mathrm{cu}$, and accordingly in the back flow zone the circumferential component of absolute velocity is $\left(S_{2}-S_{3}\right)-c_{u}^{*}$.

For the calculation of recirculation power $N_{r}$ B. Ovsyannikov uses the equation of angular momentum and assumes that the circumferential component of the absolute velocity of the forward flow $-c_{u}$, and back flow $-c_{u}^{*}$, as well as the meridian component $-c_{m}$, can be replaced by their average values. Based on the equality of the surfaces $S_{1}-S_{2}$ and $S_{2}-S_{3}$, we, thus, obtain

$$
\begin{gathered}
N_{r}=\rho_{2} u_{2} c_{m \cdot a}\left(c_{u \cdot a}-c_{u \cdot a}^{*}\right) \pi D_{2} b_{2}\left(1-\overline{F_{a}}\right)=\frac{c_{m \cdot a}}{u_{2}} \times \\
\times \frac{c_{u \cdot a}-c_{u \cdot a}^{*}}{u_{2}} \cdot \rho u_{2}^{3} b_{2} D_{2} \pi\left(1-\overline{F_{a}}\right),
\end{gathered}
$$

where $\overline{F_{a}}=F_{a} /\left(b_{2} D_{2} \pi\right)$ is the relative area of the active flow region; $F_{a}$ is the area of the active flow region. 


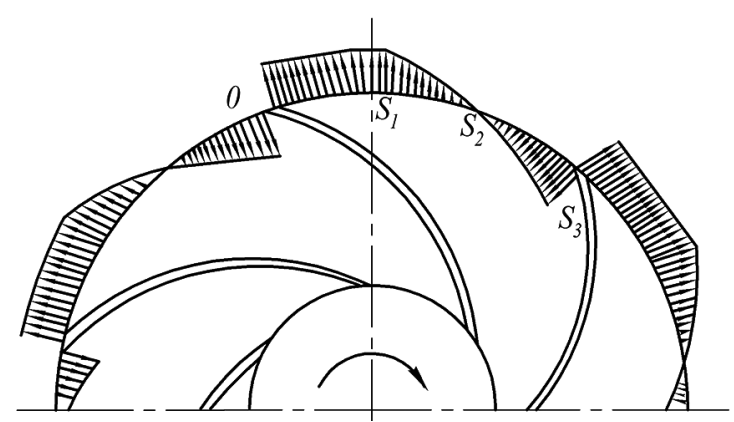

Fig. 1. To the calculation of recirculation power (by B. Ovsyannikov)

However, in practice, to determine the recirculation power, Ovsyannikov B. V. proposes to use semi-empirical dependence obtained after the transformation of equation (1) into the following form

$$
N_{r}=N_{r .0}\left(1-\overline{F_{a}}\right),
$$

where $N_{r .0}$ is recirculation power at zero flow rate through the pump $\left.\overline{\left(F_{a}\right.}=0\right)$

$$
N_{r .0}=C_{r} \frac{b_{2}}{D_{2}} \rho \omega^{3} \cdot r_{2}^{5},
$$

where $C_{r}$. is the coefficient of recirculation, including parameters $c_{u . a}-c_{u . a}^{*} / u_{2}$ and $c_{m . r} / u_{2} ; b_{2}$ is impeller outlet sectional width, $\mathrm{m} ; D_{2}$ is the impeller outlet diameter, $\mathrm{m} ; \rho$ is fluid density, $\mathrm{kg} / \mathrm{m}^{3} ; \omega$ is the angular rotor velocity of the impeller, $\mathrm{rad} / \mathrm{s} ; r_{2}$ is the impeller outlet radius, $\mathrm{m}$.

Coefficient $C_{r}$ depends on the shape and size of the volute casing, therefore, for the characteristic geometric parameter that determines the coefficient of $C_{r}$ the ratio of the maximum height of the volute casing to the outlet diameter of the impeller was adopted $h_{\max } / D_{2}=\bar{h}_{\max }$.

The experimentally obtained averaged dependence of $C_{r}$ on $\bar{h}_{\max }$ is described by the following expression

$$
C_{r}=0.92 \cdot \bar{h}_{\max } .
$$

Important conclusions about the value of the back flows and their physical nature are given in the works by K. Pfleiderer and J. Gulich. The authors consider that since the stall and recirculation depend on the three-dimensional distribution of velocity vectors in the impeller and the incoming flow, the value of the recirculation power cannot be fully described or predicted by simple methods. Therefore, most of their conclusions are based on the results of numerous pump tests:

- the flow rate at which recirculation occurs is various and depends on the design features of the pump;

- at partial load, the pump volute casing creates uneven pressure around the circumference of the impeller outlet, which determines the operation of individual passage between the blades of the impeller in various modes;

- the flow at flow rate, which corresponds to the highest value of efficiency will be continuous. The first separation of the flow occurs in the impeller and outlet casing between the flow rate with the highest efficiency and the pump operation at $Q=0$. It is important to understand that such a state is inevitable for all centrifugal pumps and recirculation at partial load cannot be avoided. However, it is possible to try to shift its beginning in the direction of the smallest possible $Q$;

- the physical mechanism of fluid recirculation at the impeller outlet is that the fluid behind the impeller outlet flows in accordance with the conservation of angular momentum, while its circumferential velocity in the volute casing decreases with increasing radius. At overload and partial load, the veloc- ity in the cross section of the volute casing does not correspond to the velocity at the impeller outlet. The pressure gradients along the radius become flatter. Therefore, similarly with flows passing through the elbow or bent channels, back flows are created in the volute casing;

- prolonged operation in the load range with strong recirculation often affects the longevity of the pump and can lead to damage due to excessive vibration or cavitation. However, some degree of recirculation is necessary to stabilize the $Q-H$ curve;

- recirculation is characteristic of all centrifugal pumps. The flow rate at which this phenomenon occurs and its value depend on the individual design parameters of the pump flowing part.

Unsolved aspects of the problem. From the analysis of publications, it follows that today there is no correct method for determining the recirculation power due to the complexity of the description of the fluid flow in the flowing part of the pump in loads that differ from the optimal one.

So equation (1) simplistically describes the fluid flow in the flowing part of the pump, because:

- it does not take into account the dependence of the distribution of the zones of active and vortex flow on the position of the passage between the blades of the impeller relative to the volute casing;

- it is assumed that the meridional component of the absolute velocity $c_{m}$ is the same for the active and vortex zones.

Also, the sectional area of the active flow is determined by a wide range of possible values. At the same time, it is assumed that there is no recirculation $N_{r: 0}=0$ at flow rate $Q \geq 0.6 Q_{o p t}$.

In equation (3), the obtained empirical dependencies of the coefficient of recirculation $C_{r}$ and the relative area of the impeller outlet occupied by the active flow $F_{a}$ are sufficiently arbitrary since their quantitative regularities are based on a hypothetical extrapolation of the rectilinear dependence of the theoretical head to the region of the low flow rate.

This assumption is not based on the real fluid flow in the flowing part of the pump, insofar the potentiality of the absolute flow of fluid in the impeller is necessary for the function $H_{m}=f(Q)$ to be rectilinear. In the loads near the optimal, the potentiality condition is confirmed experimentally, but with a decrease flow rate, intense vortex formation is observed.

Existing methodologies do not allow us to determine ways to reduce the value of recirculation losses and shift its beginning in the direction of the smallest possible value of $Q$. So improving this methodology is an urgent task.

Purpose. Improving the energy efficiency of the operational process of a low and medium specific speed centrifugal pump by taking into account the influence of the design parameters of the impeller on the value of flow recirculation at its outlet by improving the methodology for determining the recirculation power.

Methods. Modern capabilities of computers make it possible to use a numerical simulation as methods for research on the operating process of a pump.

As an object of the research, the fluid flow in the flowing part of a centrifugal pump of double suction D2000-100-2 at flow rates from 0.055 to $0.67 \mathrm{~m}^{3} / \mathrm{s}$ is considered. The speed of rotation of the pump impeller is $980 \mathrm{rpm}$, the specific speed is $n_{s}=60$.

Using the SolidWorks software, a three-dimensional fluidsolid model of the computational domain was created. It consists of an impeller with 6 blades, a semi-volute casing, and a volute casing with a diffuser.

To increase productivity and speed of calculation, the created simulation model consisted of one half of the flowing part of the pump D2000-100-2 (Fig. 2).

Using the ICEM CFD software, an unstructured mesh is generated, which is filled with tetrahedra and with prismatic layers near the solid walls of the domain.

Before setting up the numerical simulation, a mesh independence test was performed for the semi-volute casing, im- 


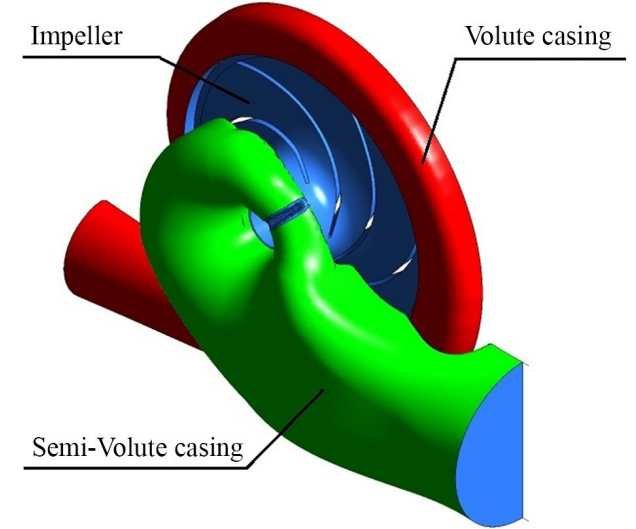

Fig. 2. Fluid-solid model of a flowing part of the pump D2000100-2

peller, and volute casing. The total number of elements of the mesh of the computational domain was about 4.5 million cells.

A numerical simulation, as a method, is based on the calculation of the Navier-Stokes and Reynolds equations in twodimensional and three-dimensional formulations. For this numerical study, the standard $k-\varepsilon$ turbulence model was used. This semi-empirical two-equation model uses Boussinesq's hypothesis and adds turbulent viscosity. To describe turbulence, two variables are used here: the kinetic energy of turbulence and the rate of dissipation of turbulence kinetic energy. This is a High-Reynolds model and, like all High-Reynolds models, it is not suitable for calculating the flow at the walls, since it does not take into account the effect of the walls on turbulence. Therefore, in generating the mesh, scalable wall functions were used.

To simplify the computational domain, the following assumptions were made:

- the fluid flow is symmetric about the axis of symmetry of the pump;

- the small radius of the fillet surfaces of the cast parts of the flowing part does not significantly affect the flow structure and the integral characteristics of the pump operating process;

- the flow in the impeller sidewall gap and leakage in impeller seals do not significantly affect the flow structure.

The following boundary conditions were specified in the ANSYS CFX software:

- the condition of adhesion of the fluid on all solid walls;

- mass flow rate and direction of the component flow velocities in the inlet section;

- pressure in the outlet section;

- zero values of the first derivatives (beyond the direction of flow) of the velocity components.

The calculation was performed in ANSYS CFX Solver at transient simulation for at least three impeller revolutions with the achievement of the frequency of head fluctuations at the outlet of the centrifugal pump. As a starting approximation of flow velocities, we used the results of stationary simulations with the output of the residual RMS Error values of the equation achieved value $10^{-4}$.

The results of transient simulations were recorded at the fourth revolution of the impeller by every 5 degrees. 72 files of numerical simulation results were recorded for each twelve flow rate in range $0.1 Q_{o p t}$ to $1.2 Q_{o p t}$ with a step of $0.1 Q_{o p t}$.

Analysis of the results and determination of the integral values of the head $-H$, flow rate $-Q$, hydraulic power $-N_{g}$, was carried out in the ANSYS CFD-Post.

The adequacy of numerical modeling is determined by comparing its results with a physical experiment - testing a pump on a test bench, according to the requirements of [5].

Graphical interpretation of changes in the main parameters of the operation process (head characteristic $H=f(Q)$, power characteristic $N=f(Q)$ and efficiency $\eta=f(Q))$ of the pump D2000-100-2 with impeller diameter $D_{2}=820 \mathrm{~mm}$ and speed of rotation of the pump impeller $980 \mathrm{rpm}$ is shown in Fig. 3.

These curves were obtained based on the results of testing workbench and numerical simulation. The solid line corresponds to the testing results, and the dotted line - to the results of the numerical simulation.

According to the results of the analysis of the data obtained, it is noted that the deviation of the head value is not more than $4 \%$, and the power value is not more than $5 \%$.

Since the discrepancy between the main integral parameters of the pump working process $(H$ and $\eta)$ does not exceed $5 \%$, then this serves as a proof which confirms the adequacy of the simulation of the pump D2000-100-2 operating process [6].

To determine the head at the impeller outlet, a cylindrical section "OutImpeller" with the diameter and width of the impeller outlet was created.

Based on the numerical simulation results and using the built-in mathematical functions ANSYS CFD-Post (Table 1), the averaged impeller head values without recirculation $-H^{*}$, impeller head with recirculation $-H$ and theoretical head $H_{T}$, were determined at the impeller outlet.

Using the mass averaging function massFlowAve, the value of the head averaged by mass flow that passes through the "OutImpeller" cylindrical surface toward the impeller outlet is determined. The massFlowAveAbs function also averages the value of the variable by the flow, taking into account its recirculation.

Results. The object of the research was the transient flow of fluid in the flowing part of a centrifugal pump.

The dynamics of the head change, taking into account and without taking into account recirculation at the impeller outlet under various operating loads of the centrifugal pump D2000100-2 were investigated. Based on the results of numerical simulation, the following was obtained:

- the dynamics of the value changes in the head with and without recirculation, as well as the value of the theoretical head at the impeller outlet, depending on the pump flow rate;

- the distribution of the relative velocity of the flow and the structure of the fluid flow in the flowing part of the centrifugal pump at different flow rate;

Table 1

Mathematical functions for the determination head values

\begin{tabular}{|c|c|}
\hline Parameter & Function \\
\hline$H^{*}$ & $\begin{array}{l}\text { (massFlowAve("Total Pressure in Stn Frame", } \\
\text { "OutImpeller") - massFlowAve("Total Pressure in } \\
\text { Stn Frame", "InPump"))/997/9.81 }\end{array}$ \\
\hline$H$ & $\begin{array}{l}\text { (massFlowAveAbs("Total Pressure in Stn Frame", } \\
\text { "OutImpeller") - massFlowAveAbs("Total Pressure } \\
\text { in Stn Frame", "InPump"))/997/9.81 }\end{array}$ \\
\hline$H_{T}$ & $\begin{array}{l}\text { torque ("Blades Impeller", } \\
\text { "z") } \cdot 3.14 \cdot 980 /(30 \cdot(\text { massFlow } \\
\text { ("OutPump") } 3600 \cdot 9.81))\end{array}$ \\
\hline
\end{tabular}

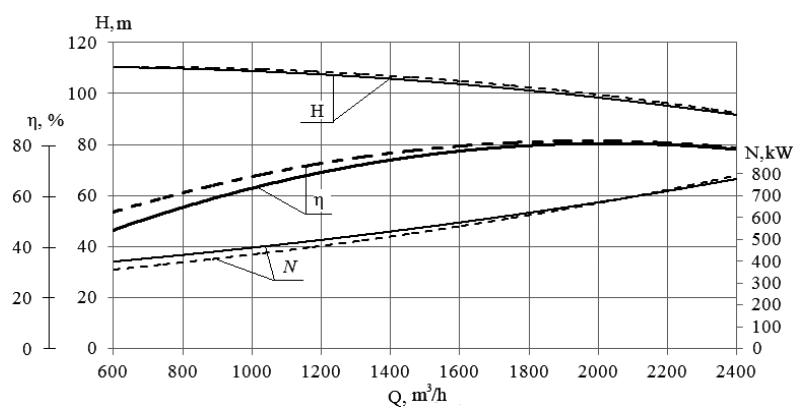

Fig. 3. $H-Q, N-Q, \eta-Q$ curve of the pump D2000-100-2 
- intensity and dynamics of changes in the amplitude of head pulsations at the impeller outlet depending on the pump flow rate.

According to the mathematical functions of Table 1, the averaged values of the head at the impeller outlet are presented in Table 2.

According to the results of numerical simulation, the theoretical impeller head and impeller head taking into account recirculation were determined - Fig. 4.

The solid line represents the changes in the theoretical head depending on the pump flow rate, and the dotted line represents the changes in the head of the pump impeller.

The power of hydraulic losses in the impeller $-N_{\text {g.l. }}$ is defined as the difference between the theoretical head $-H_{T}$ and the impeller head at its output $-H$ depending on the flow rate, $\mathrm{kW}$

$$
N_{\text {g.l. }}=\left(H_{T}-H\right) \cdot Q \cdot \rho \cdot g / 1000,
$$

where $Q$ is the flow rate, $\mathrm{m}^{3} / \mathrm{h} ; \rho$ is fluid density, $\mathrm{kg} / \mathrm{m}^{3}$.

The power of hydraulic losses calculation results, depending on the load of operation of the pump for flow rate range $(0.1-1.2) Q_{o p t}$ is given in Table 3.

Table 2

The head at the impeller outlet, depending on the flow rate

\begin{tabular}{|c|c|c|c|}
\hline Flow rate & $H, \mathrm{~m}$ & $H^{*}, \mathrm{~m}$ & $H_{T}, \mathrm{~m}$ \\
\hline $0.1 Q_{o p t}$ & 129.8 & 281.5 & 473.19 \\
\hline $0.2 Q_{o p t}$ & 130.1 & 182.2 & 270.36 \\
\hline $0.3 Q_{o p t}$ & 127.2 & 147.8 & 195.75 \\
\hline $0.4 Q_{o p t}$ & 127.7 & 137.5 & 167.93 \\
\hline $0.5 Q_{o p t}$ & 123.3 & 129.7 & 147.56 \\
\hline $0.6 Q_{o p t}$ & 121.1 & 126.3 & 138.62 \\
\hline $0.7 Q_{o p t}$ & 119.7 & 122.2 & 129.75 \\
\hline $0.8 Q_{o p t}$ & 118.5 & 118.6 & 123.88 \\
\hline $0.9 Q_{o p t}$ & 113.9 & 113.9 & 118.06 \\
\hline$Q_{o p t}$ & 111.2 & 111.2 & 115.01 \\
\hline $1.1 Q_{o p t}$ & 107.7 & 107.7 & 111.21 \\
\hline $1.2 Q_{o p t}$ & 104.8 & 104.8 & 108.27 \\
\hline
\end{tabular}

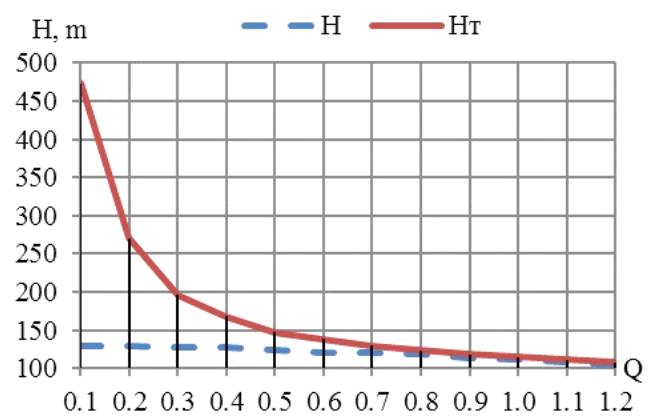

Fig. 4. Dependence of the head on the flow rate

Table 3

Power hydraulic losses

\begin{tabular}{|l|c|c|c|c|c|c|}
\hline$Q / Q_{\text {opt }}$ & 0.1 & 0.2 & 0.3 & 0.4 & 0.5 & 0.6 \\
\hline$N_{g . l .} \mathrm{kW}$ & 186.6 & 152.5 & 111.8 & 87.4 & 66 & 57.2 \\
\hline$Q / Q_{\text {opt }}$ & 0.7 & 0.8 & 0.9 & 1.0 & 1.1 & 1.2 \\
\hline$N_{g . l .} \mathrm{kW}$ & 38.2 & 22.8 & 20.5 & 20.4 & 21.3 & 22.6 \\
\hline
\end{tabular}

An increase in the $H_{T}$ theoretical head curve asymptotically toward the ordinate axis is a consequence of the occurrence of back flows at the partial load $Q<0.7 Q_{o p t}$.

In practice, the recirculation power is determined by balance tests and calculated according to the formula

$$
N_{\text {g.l. }}=\rho \cdot\left(H_{m}-H^{\prime}\right) \cdot Q_{i},
$$

where $H^{\prime}$ is the theoretical head obtained by extrapolating the rectilinear section of the dependence $H_{T}=f(Q)$ from the region of high flow rate to the region of the small one. Based on the foregoing, the rectilinear of the function $H_{T}=f(Q)$ is based on the potentiality of the absolute fluid flow in the impeller.

However, at partial load, the circumferential component of the absolute velocity is significantly reduced. Part of the fluid flows along the volute casing, falls back into the impeller. The merging of flows with different momentum of the velocities causes the appearance of intense vortex flow and countercurrents flows in partial load - Figs. 5, 6 and 7.

The distribution of the relative velocity in Fig. 6 shows that intense vortex formation and the occurrence of fluid recirculation in the flowing part of the centrifugal pump D2000-100-2 is observed in the passage between the blades of the impeller

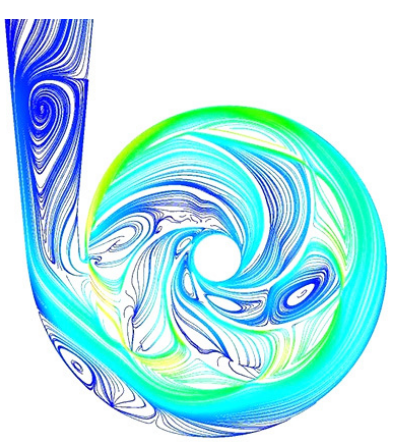

Fig. 5. The structure of the fluid flow in the flowing part of the pump at flow rate $0.1 Q_{\text {opt }}$

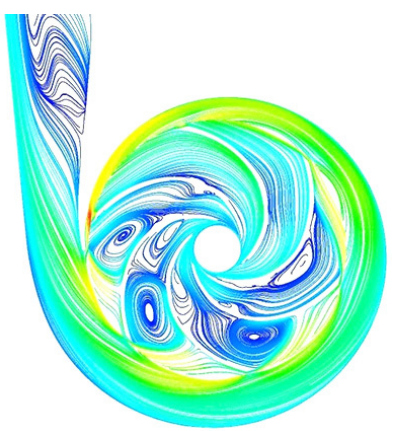

Fig. 6. The structure of the fluid flow in the flowing part of the pump at flow rate $0.6 Q_{\text {opt }}$

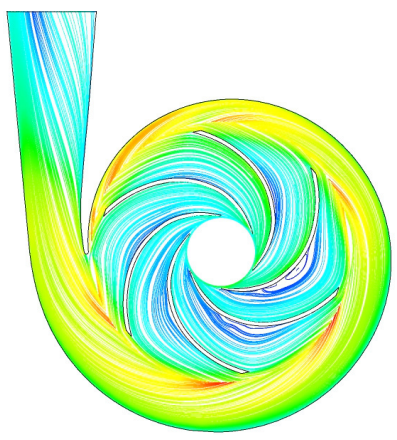

Fig. 7. The structure of the fluid flow in the flowing part of the pump at flow rate $Q_{\text {opt }}$ 
when they passing the part of the volute casing with the highest volute height and near the volute tongue. The intensity of vortex formation increases with a further decrease in the flow rate - Fig. 5. According to Fig. 7 at flow rate $-Q_{o p t}$, the flow of fluid in the flowing part of the pump D2000-1000-2 has a vortex-free uniform character.

Therefore, the recirculation power calculated by (5) takes into account not only the energy loss of the fluid recirculation but also the related vortex loss.

Based on the results of numerical simulation of the fluid flow in the flowing part of the pump, it seems possible to distinguish from the balance of power losses for hydraulic losses, the power associated only with the recirculation of the fluid at the impeller outlet.

Fluid recirculation reduces the head averaged over the outlet circumference of the impeller. The difference between the head averaged over the flow which is directed towards the outlet from the impeller $-H^{*}$ and the head averaged over the flow which is directed towards the outlet and inlet of the impeller $-H$, determines the energy loss for fluid recirculation Fig. 8. In this case, $H^{*}$ is a theoretical value that represents the possible head value in the absence of recirculation.

The solid line represents the changes in the pump impeller head, excluding recirculation, depending on the pump flow rate. The dotted line represents the changes in the pump impeller head, taking into account the recirculation.

As follows from Fig. 8 the head curve without taking account of recirculation $-H^{*}$, has similar shape of the theoretical head curve, but its value is significantly lower. This is due to the intense vortex flow in the passage between the blades of the impeller and, consequently, the additional losses in the transfer of mechanical energy of the impeller to the fluid flow.

The recirculation power $-N_{r}$ is determined on the basis of the difference in head values of $H^{*}$ and $H$ according to the equation (5) - Table 4 . The ratio of $N_{r} / N_{\text {g.l. }}$ displays the structure of energy losses for recirculation in the balance of energy losses for hydraulic losses.

As can be seen from Table 4, the absolute value of recirculation power increases when the flow rate $Q$ deviates from the optimum. At flow rate range $Q>0.7 Q_{o p t}$, the recirculation power is zero.

Analysis of qualitative and quantitative changes in the parameters of transient fluid flow in the flowing part of the pump D2000-100-2 in the flow rate range $0.1 Q_{\text {opt }}-1.0 Q_{\text {opt }}$ allows us to make the following conclusions:

- recirculation of the flow at the impeller outlet of the pump D2000-100-2 occurs at flow rates $Q \leq 0.7 Q_{\text {opt }}$, and its value increases with a decrease in flow rate, as evidenced by an increase in the difference between the head $H^{*}$ and $H$ (Fig. 8);

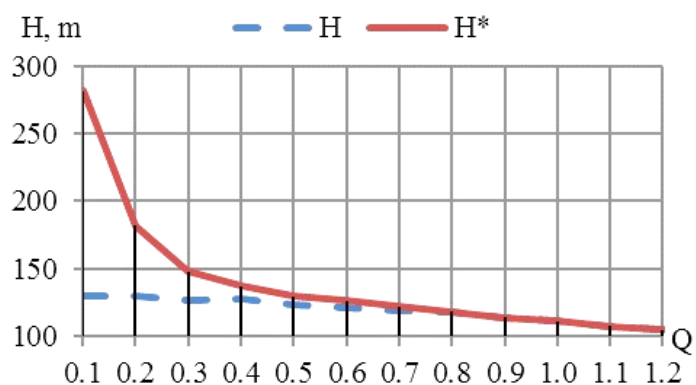

Fig. 8. Recirculation energy losses

Table 4

Recirculation power

\begin{tabular}{|l|c|c|c|c|c|c|c|}
\hline$Q / Q_{\text {opt }}$ & 0.1 & 0.2 & 0.3 & 0.4 & 0.5 & 0.6 & 0.7 \\
\hline$N_{r}, \mathrm{~kW}$ & 82.4 & 56.8 & 33.8 & 21.4 & 17.4 & 17 & 9.4 \\
\hline$N_{r} / N_{\text {g.l. }}, \%$ & 44.2 & 37.2 & 30.1 & 24.5 & 26.4 & 30 & 24 \\
\hline
\end{tabular}

- the pump volute casing creates uneven pressure distribution around the circumference of the impeller outlet at a flow rate range $0.1 Q_{o p}-0.7 Q_{o p t}$, and determines the operation of individual passage between the blades of the impeller in various modes (Figs. 5, 6);

- the fluid flow when the pump flow rate is close to optimal will be continuous, and the first separation of the flow into an active one with a direct flow of fluid at the impeller outlet and a vortex with a reverse flow occurs in the impeller and in the pump outlet at $Q \leq 0.7 Q_{\text {opt }}$;

- flow recirculation is accompanied by significant energy losses, which are one of the main components of power losses during the operation of the pump D2000-100-2 in the partload (24-44\% of the hydraulic losses power - Table 4).

Significant power losses of the pump during its operation at partial load are not the only negative consequence of recirculation. Long-term operation of the pump with significant recirculation negatively affects its durability due to the deterioration of its vibration characteristics (as a consequence, increased wear shaft seals and interstage annular impeller seals, bearing damage, fatigue failures of pump parts, and so on).

On the basis of the results of a numerical simulation, it was established that the recirculation of the flow at the impeller outlet, in addition to intense vortex formation, causes an extensive vortex breakdown when passing the passage between the blades of the impeller near the tongue of the volute casing (Figs. 5 and 6), which is the main reason for the occurrence of excessive fluid pressure pulsations when the pump is operating in the partial load. The frequency of these pulsations is superimposed on the frequency of the process of interaction of the impeller blades with the volute casing tongue (blade frequency)

$$
f_{2}=n \cdot \frac{z_{1}}{60},
$$

where $f_{2}$ is blade passage frequency, $\mathrm{Hz} ; n$ is the speed of rotation of the pump impeller, rpm; $z_{1}$ is the number of impeller blades.

The amplitude of pressure pulsations, like the value of recirculation, depends on the flow rate and increases when the pump operating load deviates from the optimal one.

Fig. 9 shows the change in the amplitude of pressure pulsations at the impeller outlet $(\Delta P)$ depending on the relative pump flow rate $Q / Q_{\text {opt }}$. The increase in the amplitude of pressure pulsations is due to the inhomogeneity of the flow in the impeller and at its outlet when the pump is operating in the flow rate range $\left(0.1 Q_{o p t}-0.7 Q_{o p t}\right)$.

Since pressure pulsations are perceived by the elements of the hydraulic network as alternating forces, the hydrodynamic vibration of the pumping equipment and the pipeline system is a consequence of pressure pulsations in the flowing part of the pump. The intensity of fluid pressure pulsations is used as an indicator of flow homogeneity and is often the only available way to obtain indirect information about the intensity and physical nature of the hydrodynamic vibration of the pump at the stage of its design.

An increase in the amplitude of pressure pulsations and power losses due to recirculation of the flow cannot be avoid-

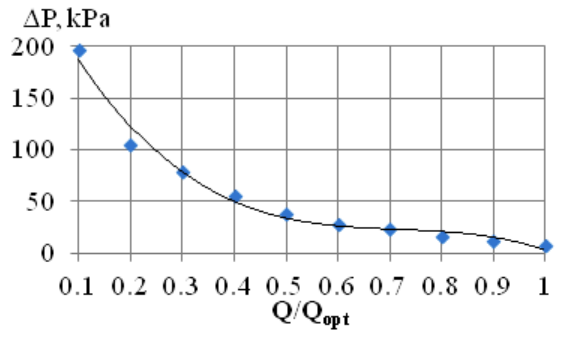

Fig. 9. RMS value of the amplitude of pressure pulsations at the outlet of the impeller of the pump D2000-100-2 
ed. However, it is possible to reduce their value and shift the beginning of recirculation in the direction of the lowest possible pump flow rate.

Since recirculation at the impeller outlet is mainly caused by a non-uniform distribution of velocity, and the reason for the recirculation of the fluid flow is the discrepancy between the design parameters of the flowing part of the pump and the hydraulic parameters of the flow, the value of recirculation can be controlled by changes in the design parameters of the flowing part impeller or changing its operating parameters.

To evaluate hydraulic losses in partial load and, in particular, losses associated with recirculation at the impeller outlet, the numerical simulation of the fluid flow in the flowing part of a centrifugal pump D2000-100-2 with various designs of the impeller and operating parameters was conducted. The following four models were analyzed:

- Base - base impeller of the pump D2000-100-2;

- No. 1 - the impeller with a reduced width of the section of the impeller outlet $b_{2}$ by $10 \%$ comparison the base impeller;

- No. 2 - the impeller with an increased number of impeller blades from 6 to 7 in comparison with the base impeller;

- No. 3 - a decrease in the angular rotor velocity of the base impeller by $20 \%$.

The degree of effectiveness of reducing recirculation with these parameters is presented in Table 5 for a centrifugal pump D2000-100-2 with a flow rate of $0.3 Q_{o p}$.

As follows from Table 5:

- an increase in the number of impeller blades slightly reduces recirculation losses, but significantly increases the total value of hydraulic losses associated with vortex formation and friction;

- reducing the angular rotor velocity of the impeller significantly reduces the value of hydraulic losses; however, this method significantly reduces the value of the head at the impeller outlet;

- reduction of the impeller width $b_{2}$ reduces the energy losses due to recirculation and the general hydraulic losses without decreasing the head at the pump outlet.

\section{Conclusions.}

1. The presented methodology makes it possible to obtain updated data on the recirculation power, taking into account the three-dimensional fluid flow in the flowing part of the centrifugal pump, and can be used in the design of low and medium specific speed centrifugal pumps, as well as in evaluating their energy efficiency during operation to the hydraulics network.

2. The results of transient numerical simulation of the fluid flow in the flowing part of a centrifugal pump confirmed that fluid recirculation at the impeller outlet is a consequence of the fact that at partial load the circumferential velocity component is significantly reduced and a part of the fluid, passing along the volute casing, falls back into the impeller. The merging of flows with different momentum of the velocities causes the appearance of intense vortex flow in position of the passage between the blades of the impeller.

3. It has been found that recirculation of the fluid reduces the head value averaged over the outlet circumference of the impeller. The difference between the head averaged over the flow, which is directed towards the outlet from the impeller

\section{Table 5}

The degree of effectiveness of reducing recirculation

\begin{tabular}{|c|c|c|c|c|}
\hline Models & $N_{r}, \mathrm{~kW}$ & $N_{\text {g.l. }}, \mathrm{kW}$ & $N_{r} / N_{\text {g.l. }}, \%$ & $\eta_{g}$ \\
\hline Base & 33.8 & 111.8 & 30.1 & 0.56 \\
\hline No. 1 & 19.2 & 90 & 21.3 & 0.606 \\
\hline No. 2 & 32.5 & 134.5 & 24.2 & 0.544 \\
\hline No. 3 & 16.9 & 49.8 & 33.8 & 0.645 \\
\hline
\end{tabular}

and the head averaged over the flow, which is directed towards the outlet and inlet of the impeller determines the energy loss for fluid recirculation. The head curve without taking account of recirculation has similar shape of the theoretical head curve, but its value is significantly lower.

4. Fluid recirculation negatively affects the vibration state of the pumping equipment, since the recirculation of the flow at the impeller outlet causes excessive pressure pulsations, the frequency of which is superimposed on the blade pass frequency, and the amplitude depends on the flow rate and increases when the pump operating load deviates from the optimal one.

5 . The methodology of determining the recirculation power based on the numerical simulation of the fluid flow in the flowing part of the centrifugal pump D2000-100-2 showed that the absolute value of the recirculation power increases when the flow rate $Q$ deviates from the optimal one. Its part in the balance of hydraulic loss power in the flow rate range $(0.7-$ $0.4) \cdot Q_{o p t}$ is $25-30 \%$, and in the flow rate range $(0.3-0.1) \cdot Q_{o p t}$ it increases to $44 \%$. For flow rate $Q>0.7 Q_{o p t}$, the recirculation power is zero.

6. Based on the kinematics of the fluid flow in the impeller and the uniformity of the velocity distribution at its outlet, to increase the energy efficiency of the operation process of a low and medium specific speed centrifugal pumps, the following ways to reduce the value of recirculation can be identified:

a) reducing the width of the impeller outlet will reduce the nonuniformity of the flow at its outlet by obtaining a more one-dimensional flow of fluid in the passage between blades;

b) increase in the number of blades provides a more uniform distribution of velocity at the impeller outlet due to the reduction of step unevenness;

c) a change in the frequency of angular rotor velocity of the impeller reduces the influence of centrifugal forces perpendicular to the main direction of flow and determining the value of recirculation.

The results presented in the article were obtained as part of the work on the research topic $0118 \mathrm{U} 003583$ "Model of a performance management system and forecasting of electric energy consumption".

\section{References.}

1. Lombardo, M. (2015). Ways to improve the efficiency of centrifugal pumps. Theoretical aspects and operating experience. Pumps. Turbines. Systems, 4(17), 34-42.

2. Lomakin, V. O., \& Chaburko, P. S. (2015). Influence of flow swirling on the hydraulic efficiency of the pump. Engineering journal, 10, 4-8.

3. Kulikov, A. A., Smolyakov, A. F., Ivanova, I. V., \& Dyukova, I. N. (2017). Thermodynamic analysis of dynamic processes in a centrifugal pump. Bulletin of the St. Petersburg Forestry Academy, 221, 197-217. https://doi.org/10.21266/20794304.2017.221.197-217.

4. Spiridonov, E. K. (2015). Characteristics and calculation of cavitation mixers. Procedia Engineering, 129, 446-450. https:// doi.org/10.1016/j.proeng.2015.12.148.

5. Rotodynamic pumps. Hydraulic performance acceptance tests. Grades 1, 2 and 3. ISO 9906:2012 (E) (2012). Switzerland: International Organization for Standardization.

6. Moskalenko, V., Sotnyk, M., \& Boiko, V. (2017). Head pulsations in a centrifugal pump. IOP Materials Science and Engineering, 233, 1-8. https://doi.org/10.1088/1757-899X/233/1/012058. 7. Valyukhov, S. G., \& Kretinin, A. V. (2016). Mathematical modeling of hydrodynamic processes in the flow path of a centrifugal pump using neural network algorithms. Pumps. Turbines. Systems, 3(20), 53-59.

8. Liu, H., Ding, J., Dai, H., Tan, M., \& Tang, X. (2014). Numerical Research on Hydraulically Generated Vibration and Noise of a Centrifugal Pump Volute with Impeller Outlet Width Variation. Mathematical Problems in Engineering, 2, 1-13.

9. Tsutsumi, K., Watanabe, S., Tsuda, S., \& Yamaguchi, T. (2017). Cavitation simulation of automotive torque converter us- 
ing a homogeneous cavitation model. European Journal of Mechanics - B/Fluids, 61(2), 263-270. https://doi.org/10.1016/j. euromechflu.2016.09.001.

10. Valyukhov, S.G., Kretinin, A.V., Galdin, D. N., \& Baranov, S. S. (2015). Optimization design of the flow path of the main oil pump using TURBO ANSYS tools. Pumps. Turbines. Systems, 14(1), 56-68.

11. ANSYS CFX 13.0 Solver Theory. Release 13.0 (2011). Retrieved from http://www.ansys.com.

12. Moskalenko, V.V., Boyko, V.S., \& Sotnik, M. I. (2016). Modeling of special operating modes of electromechanical systems of the water supply network. Electrical engineering \& Electromechanics, 4(1), 4-9.

13. Baulin, M.N., Nemtinova, D. A., Obolonskaya, E. M., Obolonskaya, O.Y., \& Shoter, P.I. (2016). Computational study of fluid flow in a centrifugal pump in Ansys CFX environment. Pumps. Turbines. Systems, 2(19), 75-79.

\section{Потужність гідравлічного гальмування в балансі гідравлічних втрат відцентрового Hacoca}

\section{В. С. Бойко , М. I. Сотник ${ }^{2}$, В. В. Москаленко ${ }^{2}$, А. К. Черноброва ${ }^{2}$}

1 - Національний технічний університет України «Київський політехнічний інститут імені Ігоря Сікорського», м. Київ, Украина, e-mail: vsboiko@bigmir.net

2 - Сумський державний університет, м. Суми, Україна, e-mail: ni.sotnik@gmail.com

Мета. Удосконалення методики визначення потужності гідравлічного гальмування відцентрових насосів низької та середньої швидкохідності з метою визначення шляхів підвищення їх енергоефективності.

Методика. Чисельний експеримент, що базується на фізичній сутності явищ гідравлічного гальмування, проведений за допомогою програмного продукту ANSYS CFX.

Результати. Досліджені та приведені показники динаміки зміни інтегральних параметрів робочого процесу відцентрового насоса Д2000-100-2 при подачах відмінних від оптимальної $\left(Q_{\text {opt }}\right)$. На основі отриманих результатів чисельного моделювання визначені значення теоретичного напору робочого колеса, а також напору на його виході з урахуванням і без урахування рециркуляції. За рахунок різниці отриманих величин напору визначена величина втрат потужності на гідравлічне гальмування та їх частка у структурі гідравлічних втрат. На основі результатів моделювання робочого процесу відцентрового насоса Д2000-100-2 частка втрат на гідравлічне гальмування на режимах $(0,7-0,4) Q_{o p t}$, становить $25-$ $30 \%$ від загальних гідравлічних втрат, а на режимах $(0,3-0,1) Q_{o p t}$ зростає до $44 \%$.

Наукова новизна. Подальший розвиток методики визначення потужності гідравлічного гальмування на основі результатів чисельного моделювання тривимірної течії рідини у проточній частині насоса з урахуванням циркуляційних вихрових процесів на виході з робочого колеса.
Практична значимість. Виділення потужності гідравлічного гальмування з балансу потужності гідравлічних втрат на етапі проектування, урахування впливу конструкційних параметрів робочого колеса на величину рециркуляції.

Ключові слова: насос, енергія, енергоефективність, рециркуляція, зворотні течії

\section{Мощность гидравлического торможения в балансе гидравлических потерь центробежного насоса}

\section{В. С. Бойко ${ }^{1}$, Н. И. Сотник ${ }^{2}$, В. В. Москаленко ${ }^{2}$ А. К. Черноброва ${ }^{2}$}

1 - Национальный технический университет Украины «Киевский политехнический институт имени Игоря Сикорского», г. Киев, Украина, e-mail: vsboiko@bigmir.net 2 - Сумской государственный университет, г. Суми, Украина, e-mail: ni.sotnik@gmail.com

Цель. Совершенствование методики определения мощности гидравлического торможения центробежных насосов низкой и средней быстроходности с целью определения путей повышения их энергоэффективности.

Методика. Численный эксперимент, базирующийся на физической сущности явлений гидравлического торможения, проведенный с помощью программного продукта ANSYS CFX.

Результаты. Исследованы и приведены показатели динамики изменения интегральных параметров рабочего процесса центробежного насоса Д2000-100-2 при подачах, отличных от оптимальной $\left(Q_{o p t}\right)$. На основе полученных результатов численного моделирования определены значения теоретического напора рабочего колеса, а также напора на его выходе с учётом и без учёта рециркуляции. За счёт разницы полученных величин напора определена величина потерь мощности на гидравлическое торможение и их доля в структуре гидравлических потерь. На основе результатов моделирования рабочего процесса центробежного насоса Д2000-100-2 доля потерь на гидравлическое торможение на режимах $(0,7-0,4) Q_{\text {opt }}$, составляет 25-30\% от общих гидравлических потерь, а на режимах $(0,3-0,1) Q o p t$ возрастает до $44 \%$.

Научная новизна. Дальнейшее развитие методики определения мощности гидравлического торможения на основе результатов численного моделирования трехмерного течения жидкости в проточной части насоса с учётом циркуляционных вихревых процессов на выходе из рабочего колеса.

Практическая значимость. Выделение мощности гидравлического торможения из баланса мощности гидравлических потерь на этапе проектирования, учёт влияния конструкционных параметров рабочего колеса на величину рециркуляции.

Ключевые слова: насос, энергия, энергоэффективность, рециркуляция, обратные течения

Recommended for publication by O. O. Liaposhchenko, Doctor of Technical Sciences. The manuscript was submitted 05.03.20. 